\title{
The 5-HT 3 Subtype of Serotonin Receptor Contributes to Nociceptive Processing via a Novel Subset of Myelinated and Unmyelinated Nociceptors
}

\author{
Karla P. Zeitz, ${ }^{1 *}$ Nicolas Guy, ${ }^{2 *}$ Annika B. Malmberg, ${ }^{*}$ Sahera Dirajlal, ${ }^{3}$ William J. Martin, ${ }^{1}$ Linda Sun, ${ }^{2}$ \\ Douglas W. Bonhaus, ${ }^{4}$ Cheryl L. Stucky, ${ }^{3}$ David Julius, ${ }^{2}$ and Allan I. Basbaum ${ }^{1}$ \\ ${ }^{1}$ Departments of Anatomy and Physiology and W. M. Keck Foundation Center for Integrative Neuroscience and \\ 2Department of Cellular and Molecular Pharmacology and Silvio Conte Center for Neuroscience Research, University of \\ California at San Francisco, San Francisco, California 94143, '3Departments of Cell Biology, Neurobiology, and Anatomy, \\ Medical College of Wisconsin, Milwaukee, Wisconsin 53226, and ${ }^{4}$ Roche Bioscience, Palo Alto, California 94304
}

\begin{abstract}
Serotonin is a major component of the inflammatory chemical milieu and contributes to the pain of tissue injury via an action on multiple receptor subtypes. Here we studied mice after genetic or pharmacological disruption of the $5-\mathrm{HT}_{3}$ receptor, an excitatory serotonin-gated ion channel. We demonstrate that tissue injury-induced persistent, but not acute, nociception is significantly reduced after functional elimination of this receptor subtype. Specifically, in the setting of tissue injury, the $5-\mathrm{HT}_{3}$ receptor mediates activation of nociceptors but does not contribute to injury-associated edema. This result is explained by the localization of $5-\mathrm{HT}_{3}$ receptor transcripts to a previously uncharacterized subset of myelinated and unmyelinated affer-
\end{abstract}

An understanding of the mechanisms that underlie pain requires an explanation of both the immediate response to injury (acute pain) and the persistence of pain in the setting of tissue injury (Dubner and Basbaum, 1994). Acute pain results from direct thermal, mechanical, or chemical activation of particular subsets of primary afferent neurons (nociceptors). The persistent component of the pain response, in contrast, is associated with the production and release of multiple inflammatory factors, including neurotransmitters, eicosanoids, and protons (Rang et al., 1994). These act in concert not only to maintain activity of primary afferent nociceptors and sustain pain but also to heighten nociceptor sensitivity, such that innocuous stimuli produce pain. Serotonin [5-hydroxytryptamine (5-HT)], a major neurotransmitter component of the inflammatory chemical milieu, may be

Received Sept. 17, 2001; revised Nov. 9, 2001; accepted Nov. 19, 2001.

This work was supported by National Institutes of Health Grants NS 21445 and 14627 (A.I.B.), NS 40538 (C.L.S), and DE08973 (A.I.B. and D.J.), a National Institute of Mental Health Silvio Conte Center grant (D.J.), an unrestricted gift from Bristol Myers Squibb (A.I.B), a National Science Foundation predoctoral fellowship (K.P.Z.), and a postdoctoral fellowship from the Human Frontier Science Program Organization (N.G.). We thank Jeannie Poblete and Joyce Kwan for expert technical assistance.

*K.P.Z., N.G., and A.B.M. contributed equally to this work.

Correspondence should be addressed to Allan Basbaum, Department of Anatomy, University of California at San Francisco, 513 Parnassus Avenue, Box 0452, San Francisco, CA 94143. E-mail: aib@phy.ucsf.edu.

N. Guy's present address: Centre National de la Recherche Scientifique, l'Institut de Pharmacologie Moléculaire et cellulaire, 06560 Valbonne, France.

A. B. Malmberg's present address: NeurogesX, 969C Industrial Road, San Carlos, CA 94070.

W. J. Martin's present address: Merck and Co., P.O. Box 2000, RY80Y-145, Rahway, NJ 07065.

Copyright (C) 2002 Society for Neuroscience $\quad 0270-6474 / 02 / 221010-10 \$ 15.00 / 0$ ents, few of which express the proinflammatory neuropeptide substance P. Finally, we provide evidence that central serotonergic circuits modulate nociceptive transmission via a facilitatory action at spinal $5-\mathrm{HT}_{3}$ receptors. We conclude that activation of both peripheral and central $5-\mathrm{HT}_{3}$ receptors is pronociceptive and that the contribution of peripheral $5-\mathrm{HT}_{3}$ receptors involves a novel complement of primary afferent nociceptors.

Key words: serotonin; 5- $\mathrm{HT}_{3}$ receptor; inflammatory pain; primary afferent nociceptors; descending pain modulation; neurogenic inflammation released from platelets, mast cells, or basophils that infiltrate an area of tissue damage (Dray, 1995). Once released, serotonin is free to interact with a number of molecularly distinct receptor subtypes expressed by primary afferent nociceptors, including the 5- $\mathrm{HT}_{3}$ receptor $\left(5-\mathrm{HT}_{3} \mathrm{R}\right)$ (Martin et al., 1998; Hamon and Bourgoin, 1999).

Unlike all other known serotonin receptor subtypes, which are G-protein-coupled, the $5-\mathrm{HT}_{3} \mathrm{R}$ is a member of the nicotinic acetylcholine superfamily of excitatory ligand-gated ion channels (Maricq et al., 1991). Functional homopentameric serotoningated channels are formed when a single cDNA encoding the $5-\mathrm{HT}_{3} \mathrm{R}-\mathrm{A}$ subunit is expressed in heterologous systems (Maricq et al., 1991). The recent identification of a second subunit gene, 5-HT ${ }_{3} \mathrm{R}-\mathrm{B}$ (Davies et al., 1999), provides molecular evidence that some native $5-\mathrm{HT}_{3} \mathrm{Rs}$ may exist as heteromeric complexes. However, because $5-\mathrm{HT}_{3} \mathrm{R}-\mathrm{B}$ subunits cannot form functional ion channels on their own, the $5-\mathrm{HT}_{3} \mathrm{R}-\mathrm{A}$ subunit is believed to constitute an essential component of all serotonin-gated ion channels.

Importantly, peripheral injection of serotonin evokes acute pain that is attenuated by relatively selective $5-\mathrm{HT}_{3} \mathrm{R}$ antagonists (Richardson et al., 1985; Sufka et al., 1992). Few studies, however, have addressed the relative contribution of the $5-\mathrm{HT}_{3} \mathrm{R}$ to both acute and persistent pain, in part because it is difficult to sustain receptor antagonism in vivo using purely pharmacological methods. Moreover, some 5- $\mathrm{HT}_{3} \mathrm{R}$ antagonists show unusual, nonlinear dose-response relationships or exhibit actions at other serotonin receptor subtypes that are found in primary afferent nociceptors (most notably, blockade of 5-HT $\mathrm{R}$ by ICS 205-930) (Bockaert et al., 1990). Obviously, these characteristics may con- 
found the design or interpretation of in vivo pharmacological experiments. Indeed, such limitations may account for the controversy concerning the contribution of the spinal $5-\mathrm{HT}_{3} \mathrm{R}$ to nociceptive processing, in which both pronociceptive and antinociceptive effects of antagonists have been reported (Glaum et al., 1990; Alhaider et al., 1991; Ali et al., 1996).

To provide a more definitive assessment of the contribution of the $5-\mathrm{HT}_{3} \mathrm{R}$ to nociceptive processing, we generated mutant mice lacking the $5-\mathrm{HT}_{3} \mathrm{R}-\mathrm{A}$ subunit and characterized their behavior in models of acute and persistent pain. Although these animals show normal acute pain responses, they exhibit significantly reduced persistent pain behavior in the setting of tissue injury, without a change in the magnitude of the associated inflammatory response. At the cellular level, this may be explained by our observation that $5-\mathrm{HT}_{3} \mathrm{R}$-As are not expressed in the substance $\mathrm{P}$ (SP)-containing afferents that are necessary for the plasma extravasation component of neurogenic inflammation (Lembeck et al., 1982). Rather, our data suggest that serotonin, via an action at $5-\mathrm{HT}_{3} \mathrm{Rs}$, contributes to specific features of tissue injury-induced pain by activating both myelinated $\mathrm{A} \delta$-nociceptors and a previously undefined subset of C-fibers.

\section{MATERIALS AND METHODS}

Gene targeting. 5- $\mathrm{HT}_{3} \mathrm{R}-\mathrm{A}$ cDNA probes were used to identify genomic clones from a 129 mouse genomic DNA library. The targeting vector was generated from an $8 \mathrm{~kb}$ EcoRI/ClaI restriction fragment containing exons 5-9 of the 5- $\mathrm{HT}_{3} \mathrm{R}-\mathrm{A}$ gene. Exon 7 and 8 encoding transmembrane domains 1, 2, and 3 of the protein were deleted with BAL 31 and replaced by a PGKneo cassette for positive selection of recombinants. An HSV-TK cassette was subcloned downstream of the homologous region for negative selection. The targeting vector $(50 \mu \mathrm{g})$ was linearized with Not I and electroporated (240 V/500 $\mu \mathrm{F}$; Genepulser; Bio-Rad, Hercules, CA) into 129-derived embryonic stem (ES) cell line JM1 [generously provided by R. Pedersen and J. Meneses (University of California at San Francisco, San Francisco, CA)]. After electroporation, transfected ES cells were allowed to recover for $48 \mathrm{hr}$ in nonselective medium and then were grown for $8 \mathrm{~d}$ in medium containing $350 \mu \mathrm{g} / \mathrm{ml} \mathrm{G} 418$ and $0.2 \mu \mathrm{M}$ Ganciclovir. One hundred eighty clones surviving drug selection were screened for homologous recombination by Southern blot analysis. DNA was digested with Bbu1 $(S p h \mathrm{I})$ or $P s t \mathrm{I}$, and filters were probed with an external $3^{\prime}$ or $5^{\prime}$ genomic probe, respectively. Two clones underwent correct targeting of the genetic locus and were also checked for random integration events using a PGKneo probe. Targeted clones were injected into C57BL/6 blastocysts to generate chimeras. Highly chimeric males were crossed to $\mathrm{C} 57 \mathrm{BL} / 6 \mathrm{~J}$ or $\mathrm{B} 6 \mathrm{D} 2$ females, and germ line transmission of the mutation was assessed by Southern blot analysis of tail DNA from agouti pups. Heterozygotes were then intercrossed to generate wild-type, heterozygous, and null mutant mice used in this study.

Southern and Northern blotting. Genomic DNA was digested overnight with appropriate restriction enzymes, size fractionated on a $0.6 \%$ agarose gel, and transferred onto a nylon membrane $\left(\right.$ Hybond $\mathrm{N}^{+}$; Amersham Biosciences, Arlington Heights, IL) in $0.4 \mathrm{M} \mathrm{NaOH}$. Hybridization with ${ }^{32} \mathrm{P}$-labeled DNA probes was performed overnight at $65^{\circ} \mathrm{C}$ in $1 \mathrm{M}$ $\mathrm{NaCl}, 1 \% \mathrm{SDS}$, and 10\% dextran sulfate (Amersham Biosciences). Poly $\left(\mathrm{A}^{+}\right)$RNA was prepared from DRG of adult wild-type, heterozygous, or null mutant mice (35 ganglia per group) using a Micro-FastTrack kit (Invitrogen, San Diego, CA). RNAs were separated on a $1 \%$ agaroseformaldehyde gel, transferred to a nylon membrane (Hybond $\mathrm{N}^{+}$; Amersham Biosciences), and hybridized overnight at $65^{\circ} \mathrm{C}$ in $1 \mathrm{M} \mathrm{NaCl}, 1 \%$ SDS, and $10 \%$ dextran sulfate with a ${ }^{32} \mathrm{P}$-labeled full-length $5-\mathrm{HT}_{3} \mathrm{R}-\mathrm{A}$ or $\mathrm{P}_{2} \mathrm{X}_{3}$ cDNA probe.

Receptor autoradiography. Mice were killed by asphyxiation with $\mathrm{CO}_{2}$, and brains were removed and frozen in $n$-methylbutane that had been chilled with dry ice. Cryostat sections $(10 \mu \mathrm{m})$ were thaw-mounted onto Superfrost Plus (VWR) slides and stored at $-70^{\circ} \mathrm{C}$. Sections were rehydrated for $60 \mathrm{~min}$ with $5 \mathrm{mM}$ HEPES buffer, $\mathrm{pH} 7.4$, and covered with $150 \mu \mathrm{l}$ of $\left[{ }^{3} \mathrm{H}\right] \mathrm{BRL} 43696$ (Wong et al., 1993) (10 $\mathrm{nM}$ in HEPES buffer, $\mathrm{pH}$ 7.4). Nonspecific binding was defined on matched sections by the inclusion of zacopride $(100 \mu \mathrm{M})$. After $60 \mathrm{~min}$ incubation at room temperature, sections were washed twice in ice-cold HEPES buffer.
Slides were dried, opposed to $\left[{ }^{3} \mathrm{H}\right]$ Hyperfilm (Amersham Biosciences), mounted in light tight cassettes, and stored at room temperature for 4 weeks. Films were developed with Kodak D-19 $\left(22^{\circ} \mathrm{C}\right.$; Eastman Kodak, Rochester, NY) and analyzed with the MCID (microcomputer imaging device) system (Imaging Research Inc., St. Catharines, Ontario, Canada).

Assessment of pain behavior. All experiments were approved by the University of California at San Francisco Institutional Animal Care and Use Committee. Reflex withdrawal responses to heat and mechanical stimuli, abdominal stretch response to acetic acid $(0.6 \%)$ or serotonin $(1.0 \mathrm{mg} / \mathrm{kg})$, and licking in the formalin test $(2.0 \%, 10 \mu \mathrm{l})$ were assessed as described previously (Hargreaves et al., 1988; Cao et al., 1998). Motor function was assessed on an accelerating rotarod treadmill. Licking behavior was measured after intraplantar injection of serotonin (10 $\mu \mathrm{g} / 10 \mu \mathrm{l})$ or of the $5-\mathrm{HT}_{3} \mathrm{R}$ agonists 2 -methylserotonin $(10 \mu \mathrm{g} / 10 \mu \mathrm{l})$ or $m$-chlorophenyl-biguanide (mCPBG) $(1.0 \mu \mathrm{g} / 10 \mu \mathrm{l})$. Paw swelling was measured with a spring-loaded caliper (Mitutoyo, Kanagawa, Japan). To establish a persistent tissue injury with inflammation, we made an intraplantar injection of complete Freund's adjuvant (CFA) $(10 \mu \mathrm{g} / 20 \mu \mathrm{l})$ (Cao et al., 1998). To examine changes in a model of neuropathic pain, we studied animals after partial sciatic nerve section (Malmberg and Basbaum, 1998). Mechanical and thermal sensitivity were measured with von Frey filaments and a radiant heat stimulus at 1 and $3 \mathrm{~d}$ after the CFA and $3,7,10$, and $14 \mathrm{~d}$ after the nerve injury.

Spinal cord electrophysiology. Single units were recorded as described previously (Martin et al., 2001). Neurons had mechanosensitive receptive fields on the plantar surface of the paw and were characterized by their responses to both brush and noxious heat $\left(49^{\circ} \mathrm{C}\right)$. Formalin $(2 \%, 20 \mu \mathrm{l})$ was injected into the center of the receptive field at time 0 , and neuronal firing was recorded for $1 \mathrm{hr}$. We calculated the total number of spikes evoked during the first $(0-10 \mathrm{~min})$ and second $(10-60 \mathrm{~min})$ phase after formalin injection and used the Mann-Whitney $U$ test to compare formalin-evoked neuronal activity between the groups of animals.

In situ hybridization and immunohistochemistry. Cryostat sections (12 $\mu \mathrm{m})$ from lumbar DRG were prepared from wild-type and mutant mice. Digoxigenin-labeled cRNA probes were transcribed from a linearized Bluescript vector (Stratagene, La Jolla, CA) containing the entire $5-\mathrm{HT}_{3} \mathrm{R}$ cDNA, except for a small 5' fragment. Hybridization was conducted as described previously (Tecott et al., 1993). The hybridized probe was visualized by incubation with alkaline phosphatase-conjugated anti-digoxigenin Fab fragments (Roche Products, Hertforshire, UK), followed by reaction with 4-nitro-blue tetrazolium chloride and 5-bromo4-chloro-3-indolyl-phosphate (Roche Products) according to the specifications of the manufacturer. Sections were then incubated overnight in one of several antisera: rabbit anti-substance $\mathrm{P}(1: 10,000$; Peninsula Laboratories, Belmont, CA), mouse anti-N-52 (1:000; Sigma, St. Louis, MO), rabbit anti-calcitonin gene-related peptide (1:1000; Peninsula Laboratories), guinea pig anti-VR1 (1:500), or biotinylated IB4 (1:50; Vector Laboratories, Burlingame, CA). The primary antisera were localized by immunofluorescence with either $\mathrm{Cy3}$ - or $\mathrm{Cy} 2$-conjugated secondary antisera (1:600; Jackson ImmunoResearch, West Grove, PA). To assess the total number of cells in a given section, we used the FluroNissl Green stain from Molecular Probes (Eugene, OR). Cell diameters were measured using NIH Image.

Skin-nerve electrophysiology. The skin-saphenous nerve preparation was performed as described previously (Stucky and Lewin, 1999). Extracellular recordings of single fibers were made from the desheathed saphenous nerve of wild-type and mutant mice $(n=20)$. The conduction velocity of each fiber was determined by electrically stimulating its receptive field (Koltzenburg et al., 1997). Mechanical thresholds were assessed, and fibers were considered to be nociceptors if their von Frey thresholds were $\geq 2.0 \mathrm{mN}$ (range, $2.0-22 \mathrm{mN}$ ) and if they exhibited slowly adapting responses to a sustained mechanical stimulus. To examine chemical responsiveness, we sealed off the receptive field with a metal ring and applied $\mathrm{mCPBG}(10 \mu \mathrm{M})$ for $3 \mathrm{~min}$, washed for $2 \mathrm{~min}$, and finally applied capsaicin $(10 \mu \mathrm{M})$ for $3 \mathrm{~min}$. We measured the number of chemical-induced action potentials during the first minute of application; a fiber was considered responsive if the drug elicited at least three action potentials.

Whole-cell recordings from isolated DRG neurons. Lumbar ganglia (L1-L6) from adult null mutant and wild-type mice $(n=25)$ were removed, dissociated, and cultured (Stucky and Lewin, 1999). Whole-cell recordings were performed $18-30 \mathrm{hr}$ after plating. We distinguished nociceptors from non-nociceptors by the presence of an inflection on the falling phase of the somal action potential as described previously 
(Stucky and Lewin, 1999), and only neurons with an inflection on the falling phase of the action potential were included in this study. In voltage-clamp mode, neurons were superfused with mCPBG $(3 \mu \mathrm{M})$ for $10 \mathrm{sec}$, followed by a 2 min wash and subsequently superfused with capsaicin $(3 \mu \mathrm{M})$. We considered a neuron responsive if an inward current $>100 \mathrm{pA}$ was induced. Directly after recording, IB $_{4}$-FITC (10 $\mu \mathrm{g} / \mathrm{ml}$ ) was added to the recording chamber for $10 \mathrm{~min}$, and the presence of $\mathrm{IB}_{4}$ binding was determined. For N-52 staining, neurons plated on Cell-Locate cover glasses (Eppendorf Scientific, Westbury, NY) were fixed with $4 \%$ paraformaldehyde for $10 \mathrm{~min}$, washed in PBS, and incubated overnight with mouse anti-N-52 antibody (1:10,000; Sigma), followed by Cy3-conjugated anti-mouse secondary antisera (1:1000; Jackson ImmunoResearch).

\section{RESULTS}

\section{5-HT ${ }_{3} \mathrm{R}-\mathrm{A}$ gene disruption}

The $5-\mathrm{HT}_{3} \mathrm{R}-\mathrm{A}$ gene was disrupted by deleting exons 7 and 8 , which encode the first three putative transmembrane domains of the channel protein (Werner et al., 1994), and inserting a neomycin expression cassette (PGKneo) at this position (Fig. 1a). Homologous recombination of the targeting vector and germ line transmission of the disrupted locus were verified by Southern blotting (Fig. 1b). Northern blot analysis of message in dorsal root ganglia showed that null mutant mice were devoid of $5-\mathrm{HT}_{3} \mathrm{R}-\mathrm{A}$ transcripts (Fig. 1c). Heterozygotes expressed reduced transcript levels compared with wild-type siblings. Matings between heterozygous mice produced wild-type, heterozygous, and homozygous mutant offspring in normal Mendelian ratios. Homozygous mutant (knock-out) animals were healthy, fertile, and did not differ in appearance from wild-type siblings. Gross motor ability, including walking on a rotating rod, was comparable in wild-type and mutant mice.

Quantitative autoradiography using the selective $5-\mathrm{HT}_{3} \mathrm{R}$ radioligand $\left[{ }^{3} \mathrm{H}\right]-\mathrm{BRL} 43694$ (granisetron) (Wong et al., 1993) revealed that null mutant mice lacked functional receptors in three areas that contain relatively high densities of $5-\mathrm{HT}_{3} \mathrm{R}$ ligand binding sites: the nucleus of the solitary tract, the area postrema, and the trigeminal nucleus caudalis (Gehlert et al., 1991). In agreement with the Northern blot analysis, binding in the heterozygotes was approximately one-half that of wild-type mice (Fig. 1d).

\section{Acute pain responses are normal, but persistent pain responses are reduced in $5-\mathrm{HT}_{3} \mathrm{R}-\mathrm{A}$ mutant mice}

We compared wild-type and 5- $\mathrm{HT}_{3} \mathrm{R}-\mathrm{A}$ mutant mice in several acute pain models, including the hot-plate, tail-flick, and Hargreave's paw withdrawal (1988) tests of thermal nociception, the tail pinch test of mechanical nociception, and the intraperitoneal acetic acid (i.e., low pH-induced) stretching test of visceral nociception. In each modality, we found no difference between the wild-type and mutant mice (Fig. 2). On the other hand, the stretching response produced by intraperitoneal serotonin was significantly reduced in the mutant mice (Fig. 2). These results establish that the $5-\mathrm{HT}_{3} \mathrm{R}$ has functional relevance to the direct actions of serotonin, but that this receptor does not contribute to the acute pain produced by physiologically relevant stimuli.

We next examined the animals in a model of persistent pain using the formalin test. In this paradigm, a dilute formalin solution is injected into the plantar surface of the hindpaw, and pain-related behavior (licking) is scored in two phases (for review, see Tjølsen et al., 1992). The first phase $(\sim 0-10 \mathrm{~min})$ is produced by direct activation of nociceptors and therefore provides a measure of acute chemical pain. The second phase results in part from a delayed inflammatory response in the injected paw

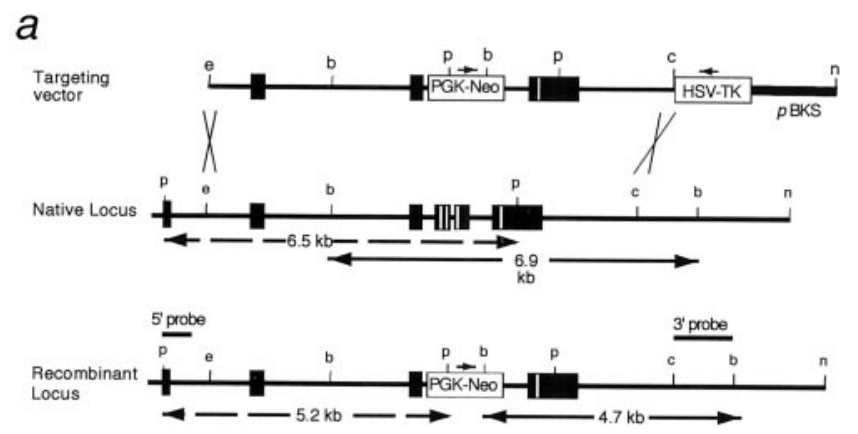

$b$
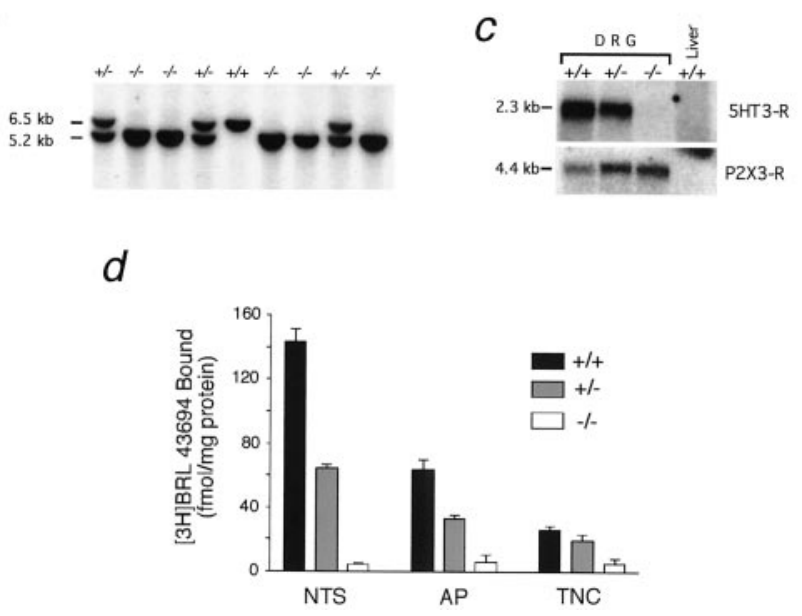

Figure 1. Functional disruption of the 5- $\mathrm{HT}_{3} \mathrm{R}-\mathrm{A}$ gene. $a$, The structure of the native and disrupted $5-\mathrm{HT}_{3} \mathrm{R}-\mathrm{A}$ alleles are shown, together with the location of the $5^{\prime}$ and $3^{\prime}$ flanking probes used to characterize recombination products. The disrupted allele lacks three of the four putative transmembrane domains (white vertical bars) of the receptor and contains a neomycin selection cassette $(P G K-N e o)$ in their place. $b$, Southern blot analysis of PstI-digested tail DNA from wild-type $(+/+)$, heterozygous $(+/-)$, or null mutant $(-/-) 5-\mathrm{HT}_{3} \mathrm{R}-\mathrm{A}$ mice using the $5^{\prime}$ flanking fragment as probe. Wild-type and mutant bands appear at 6.5 and $5.2 \mathrm{~kb}$, respectively. $c$, Northern blot analysis of DRG mRNA from wild-type, heterozygous, and null mutant $5-\mathrm{HT}_{3} \mathrm{R}-\mathrm{A}$ mice shows that knock-out animals lack $5-\mathrm{HT}_{3} \mathrm{R}-\mathrm{A}$ transcripts. Expression of ATP-gated ion channel (P2X3-R) mRNA (Chen et al., 1995; Lewis et al., 1995) served as a positive control for sample preparation and loading, and liver mRNA served as a negative control for probe specificity. $d$, Null mutant mice lack specific binding sites for the $5-\mathrm{HT}_{3}$-selective radioligand $\left[{ }^{3} \mathrm{H}\right] \mathrm{BRL} 43694$. In situ autoradiography was performed for three brain regions known to contain $5-\mathrm{HT}_{3} \mathrm{Rs}$, including the nucleus of the solitary tract $(N T S)$, area postrema $(A P)$, and trigeminal nucleus caudalis $(T N C)$. Values represent average site densities as determined for nine tissue sections prepared from each of three animals per genotype.

and thus serves as a model of persistent pain resulting from tissue injury. Consistent with acute pain being intact in null mutant animals, we found that first-phase pain behavior did not differ in wild-type and mutant mice. In contrast, the second phase of pain behavior was significantly reduced in the mutant animals, indicating that $5-\mathrm{HT}_{3} \mathrm{Rs}$ are important contributors to the nociceptive circuits that produce persistent pain (Fig. $3 a$ ).

Because a decrease in the second phase pain behavior in the formalin test could result from changes at many levels of the neuroaxis (Wei et al., 2001), we examined electrophysiological responses of neurons in the deep dorsal horn (in the region of lamina V) after an intraplantar formalin injection. We first characterized the neurons as multireceptive based on their responses to both innocuous (brush) and noxious $\left(49^{\circ} \mathrm{C}\right)$ stimuli. As for the 

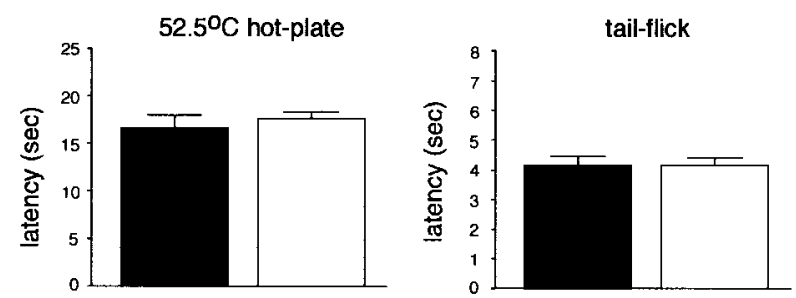

thermal paw stimulation
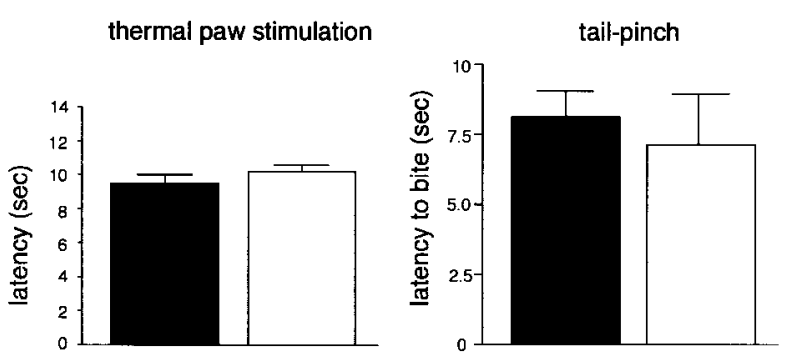

i.p. acetic acid $(0.6 \%)$
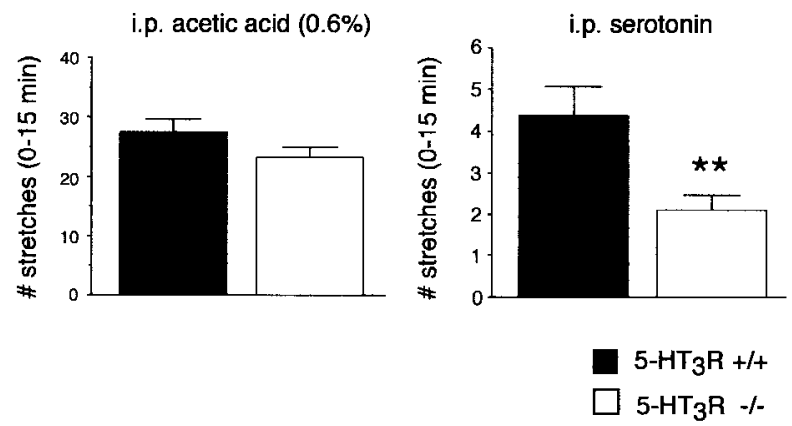

Figure 2. The $5-\mathrm{HT}_{3} \mathrm{R}$ is not required for acute pain responses to thermal, mechanical, or visceral stimuli but does contribute to behavioral indices of pain produced by serotonin. The response latencies in the $52.5^{\circ} \mathrm{C}$ hot-plate, Hargreave's thermal paw withdrawal, and tail-flick tests of thermal nociception, in the tail-pinch test of mechanical nociception, and in the visceral pain response (stretching) to intraperitoneal acetic acid were similar in 5-HT $\mathrm{HT}_{3} \mathrm{R}$ mutant and wild-type mice $(p>0.05 ; t$ test; $n=5$ per group). In contrast, the visceral response to intraperitoneal (i.p.) serotonin was significantly reduced in the mutant mice $(p<0.01 ; t$ test; wild type, $n=8$ per group; knock-out, $n=10$ per group).

behavioral profile, formalin evoked two phases of dorsal horn neuronal firing as shown previously in rats (Dickenson and Sullivan, 1987). The first phase consisted of an immediate increase in the firing rate that lasted for $\sim 2 \mathrm{~min}$; there was no difference in the total number of spikes evoked in the first phase (0-10 min) between wild-type (mean \pm SEM; $1236 \pm 473$ ) and mutant $(1770 \pm 617)$ mice (Fig. $3 b, c)$. After a quiescent period, the wild-type mice exhibited a second phase of firing in which there was a marked increase in total spikes (4082 \pm 1726), which mirrored the second phase of pain behavior. Consistent with the observed deficit in second phase pain behavior in null mutant mice, the magnitude of neuronal firing during the second phase in the knock-out animals was dramatically reduced $(784 \pm 410 ; p=$ $0.0175)$.

Finally, to identify the contribution of peripheral versus central $5-\mathrm{HT}_{3} \mathrm{Rs}$ to sustained formalin-evoked pain behaviors, we used a pharmacological approach to inhibit receptor function in specific sites. We found that peripheral (intraplantar) injection of the $5-\mathrm{HT}_{3} \mathrm{R}$ antagonist ondansetron reduced second, but not first, phase pain behavior in wild-type mice (Fig. 4a). Because $5-\mathrm{HT}_{3} \mathrm{Rs}$ are also found on the central (spinal) terminals of primary afferents and on dorsal horn interneurons (Hamon et al., 1989; Kia et al., 1995), we also examined the effect of ondansetron administered directly into the CSF (intrathecally). As observed after peripheral injection, intrathecal ondansetron dose dependently suppressed the second-phase paw-licking behavior in the formalin test (Fig. 4b) but had no effect on the first (acute pain) phase (data not shown). These pharmacological results indicate that the reduced second-phase formalin behavior in the knockout mice likely reflects loss of peripheral and central (spinal) 5-HT 3 R activity (Oyama et al., 1996) (also see below).

\section{The $5-\mathrm{HT}_{3} \mathrm{R}$ is not required for tissue or nerve injury-induced allodynia}

In addition to producing persistent pain, tissue or nerve injury can induce a condition in which the response to noxious stimulation is exaggerated (hyperalgesia) and/or normally innocuous thermal or mechanical stimuli produce pain (allodynia) (Dubner and Basbaum, 1994). We tested the animals in a model of tissue inflammation produced by injection of CFA, as well as in a model of neuropathic pain produced by partial sciatic nerve injury (Malmberg and Basbaum, 1998). Injection of CFA produced a marked swelling of the paw and a decreased withdrawal threshold to thermal and mechanical stimuli, with similar magnitudes in $5-\mathrm{HT}_{3} \mathrm{R}$ mutant and wild-type mice ( $n=5$ per group) (data not shown). Partial nerve injury also produced a robust thermal and mechanical allodynia that did not differ between the two groups of animals ( $n=5$ per group) (data not shown). Importantly, we found that basal mechanical withdrawal thresholds, tested with calibrated von Frey hairs (Chaplan et al., 1994), did not differ in wild-type and mutant mice in the absence of injury. We conclude that the persistence of pain in the setting of injury, but not the concurrent allodynia, is dependent on $5-\mathrm{HT}_{3} \mathrm{R}$ activation.

\section{Differential contribution of peripheral $5-\mathrm{HT}_{3} \mathrm{Rs}$ to pain and inflammation}

Despite the reduction in second-phase pain behavior in mutant animals, formalin-evoked paw swelling, a key indicator of inflammatory response, did not differ from that observed in wild-type mice (44 \pm 3 and $43 \pm 4 \%$ increase in paw diameter, respectively) (Fig. 5). These results suggest that formalin-induced release of serotonin in the setting of tissue injury induces pain behavior at least in part via activation of the $5-\mathrm{HT}_{3} \mathrm{R}$, but that activity at this receptor does not contribute to concurrent edema. To directly test whether activation of $5-\mathrm{HT}_{3} \mathrm{Rs}$ is involved in edema, we assessed the magnitude of swelling produced by peripheral injection of serotonin- or $5-\mathrm{HT}_{3} \mathrm{R}$-selective agonists. As predicted, despite the differences in pain behavior, the edema produced by intraplantar serotonin did not differ in mutant and wild-type mice (Fig. 5). Paw injections of the 5- $\mathrm{HT}_{3} \mathrm{R}$ agonists $\mathrm{mCPBG}(1.0$ $\mu \mathrm{g} / 10 \mu \mathrm{l})$ or 2-methylserotonin $(10 \mu \mathrm{g} / 10 \mu \mathrm{l})$ also produced intense paw licking in the wild-type mice. Importantly, however, the $5-\mathrm{HT}_{3} \mathrm{R}$ agonists did not evoke significant paw swelling in either wild-type or null mutant mice (Fig. 5). Together, these results indicate that, when serotonin is released in the setting of tissue injury, it contributes to nociceptive processing and edema, but only the former is influenced by activation of the $5-\mathrm{HT}_{3} \mathrm{R}$.

\section{$5-\mathrm{HT}_{3} \mathrm{R}-\mathrm{A}$ is expressed by novel subset of primary afferent neurons}

The presence of $5-\mathrm{HT}_{3} \mathrm{Rs}$ on primary afferent fibers has been inferred from the decreased binding of $5-\mathrm{HT}_{3} \mathrm{R}$ radioligands in the dorsal horn after denervating the spinal cord by transection of 
a
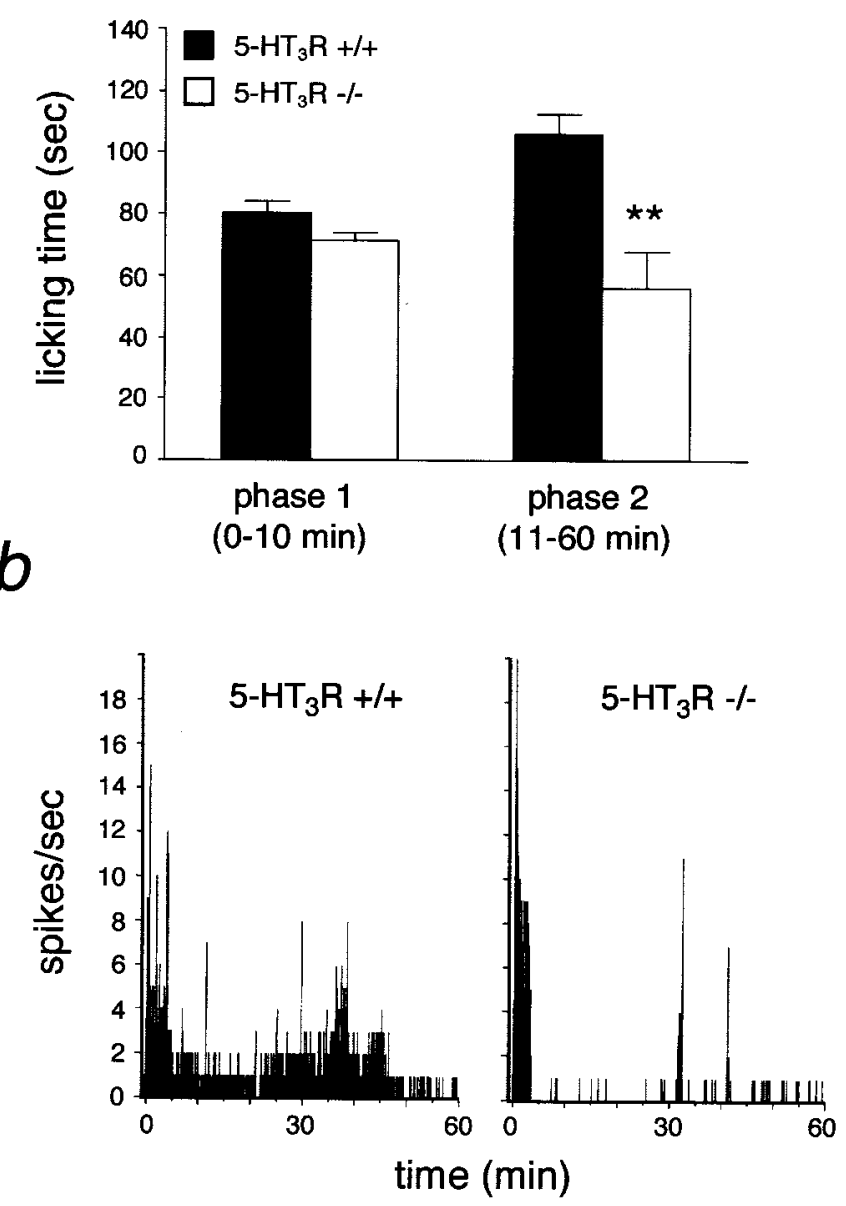

C

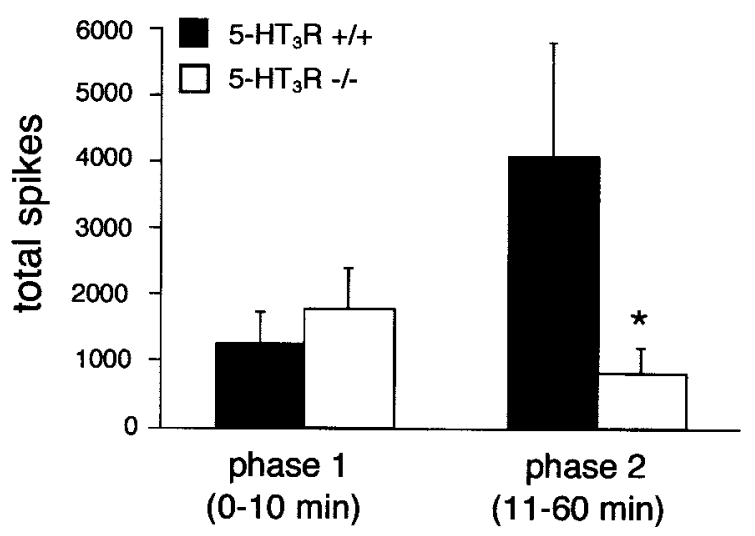

Figure 3. The $5-\mathrm{HT}_{3} \mathrm{R}$ is required for the second phase of pain behavior and of spinal cord neuronal firing in the formalin test. $a$, Formalininduced paw licking during phases $1(0-10 \mathrm{~min})$ and $2(11-60 \mathrm{~min})$ in both wild-type and 5- $\mathrm{HT}_{3} \mathrm{R}-\mathrm{A}$ null mutant mice did not differ, but the magnitude of second-phase pain behavior was significantly reduced in mutant animals $\left({ }^{* *} p<0.01 ; t\right.$ test, comparing the two groups; $n=7-8$ per group). $b$, Response of a lamina $\mathrm{V}$ neuron in the spinal cord to the injection of formalin. In wild-type mice, formalin produced a characteristic biphasic increase in neuronal activity, which resembles the time course of the behavioral response. In the $5-\mathrm{HT}_{3} \mathrm{R}$ mutant mice, the first-phase firing was comparable with wild-type mice, but there was only a modest second phase response. $c$, Summary of formalin-evoked neuronal activity; significantly fewer total spikes were recorded during the second phase in the mutant mice compared with wild-type mice $\left({ }^{*} p<\right.$ 0.01; Mann-Whitney $U$ test; $n=8$ ). a

intraplantar ondansetron

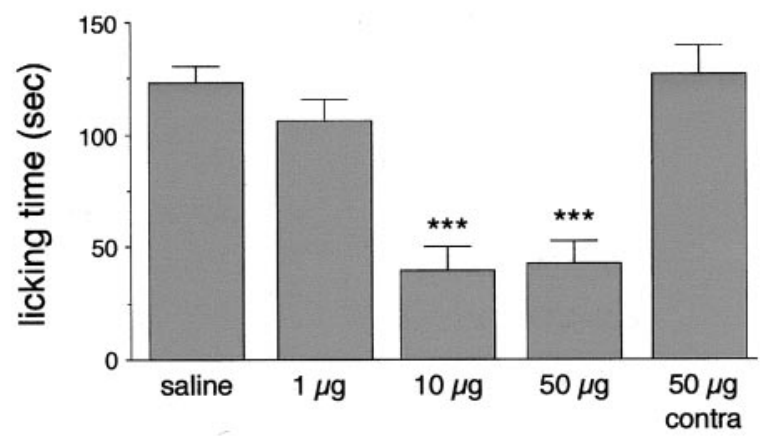

$b$

intrathecal ondansetron

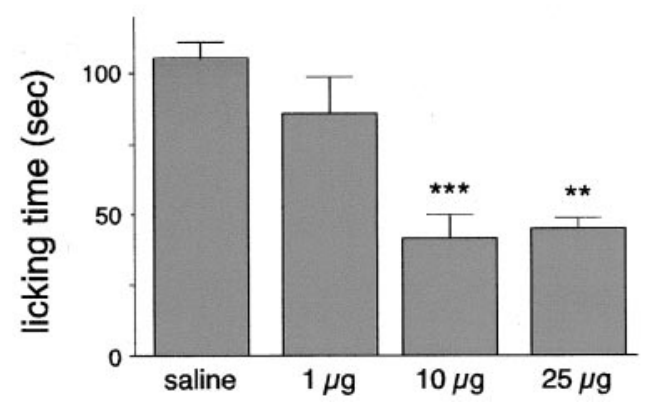

Figure 4. Both peripheral and central (spinal) $5-\mathrm{HT}_{3} \mathrm{Rs}$ contribute to persistent pain behavior. $a$, Intraplantar injection of the $5-\mathrm{HT}_{3} \mathrm{R}$ antagonist ondansetron dose dependently reduced the magnitude of pain behavior (duration of licking) during the second phase of the formalin test. Contralateral injection was without effect, indicating that the locus of the drug action was in the injected paw. $b$, Intrathecal (CSF) administration of ondansetron also produced a dose-dependent suppression of the pawlicking behavior in the second phase $\left({ }^{* *} p<0.01\right.$; ${ }^{* *} p<0.001$; StudentNewman-Keuls test, compared with saline injection; $n=5$ per group).

dorsal roots (Kidd et al., 1993) or by neonatal destruction of C-fibers with the neurotoxin capsaicin (Hamon et al., 1989). In a previous study, we demonstrated that DRG neurons express 5-HT ${ }_{3} \mathrm{R}-\mathrm{A}$ transcripts (Tecott et al., 1993). However, none of these studies identified the specific subset(s) of DRG neurons that express $5-\mathrm{HT}_{3} \mathrm{Rs}$. To directly detect $5-\mathrm{HT}_{3} \mathrm{R}$ protein in $\mathrm{DRG}$ neurons, we first tested a number of commercial and noncommercial antibodies directed against the $5-\mathrm{HT}_{3} \mathrm{R}$. Unfortunately, in every case, the staining pattern revealed in null mutants was similar, if not identical, to that observed in wild-type littermates, suggesting that none of the antisera were specific for the $5-\mathrm{HT}_{3} \mathrm{R}$. In contrast, in situ hybridization for $5-\mathrm{HT}_{3} \mathrm{R}$-A message proved to be very specific, as indicated by the complete lack of $5-\mathrm{HT}_{3} \mathrm{R}-\mathrm{A}$ mRNA in DRG sections from mutant animals (Fig. $6 a, b$ ).

Figure $6 i$ illustrates that $5-\mathrm{HT}_{3} \mathrm{R}-\mathrm{A}$ mRNA is present not only in neurons with small cell bodies (i.e., presumptive $\mathrm{C}$-fiber neurons) but is actually localized to many neurons with considerably larger diameters. In fact, $\sim 80 \%$ of $5-\mathrm{HT}_{3} \mathrm{R}$-A-positive neurons (394 of 483) immunostained for N-52, a neurofilament marker of myelinated primary afferents (Lawson and Waddell, 1991) (Fig. $6 c, d)$. These data suggest that $5-\mathrm{HT}_{3} \mathrm{Rs}$ are expressed primarily by a subpopulation of neurons with myelinated afferents, as well as by some C-fiber nociceptors. Surprisingly, we found that at most $13 \%$ (61 of 483 ) of neurons that express the $5-\mathrm{HT}_{3} \mathrm{R}-\mathrm{A}$ 


\section{Edema}

$$
\text { formalin }
$$
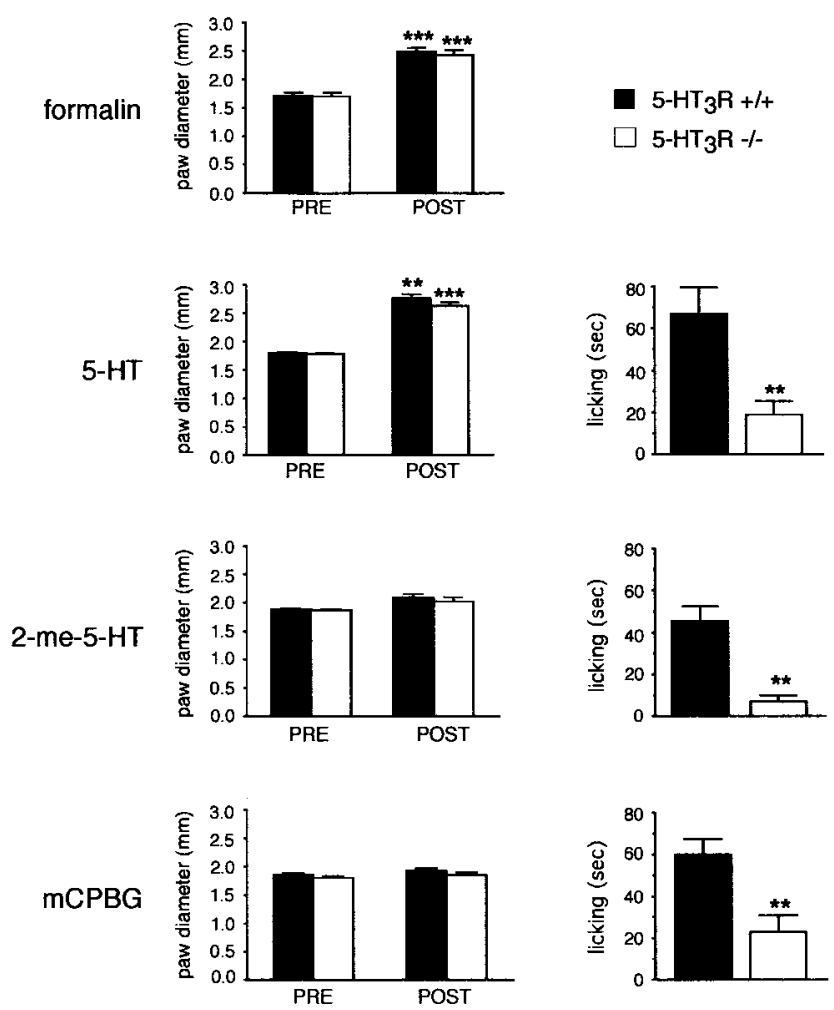

Figure 5. The peripheral 5- $\mathrm{HT}_{3} \mathrm{R}$ contributes to nociceptive processing but not to paw edema induced by injury. Paw diameters before injection of algesic agents did not differ in wild-type and null mutant mice. Intraplantar injection of $2.0 \%$ formalin or $10 \mu \mathrm{g}$ of serotonin (5-HT) produced a comparable increase in paw diameter, a measure of inflammation, in $5-\mathrm{HT}_{3} \mathrm{R}$ mutant and wild-type mice $\left({ }^{* * *} p<0.001 ; t\right.$ test; $n=$ $7-8$ per group). Consistent with these observations, intraplantar injection of the 5- $\mathrm{HT}_{3} \mathrm{R}$ agonists 2-methyl 5-HT $(10 \mu \mathrm{g})$ or mCPBG $(1.0 \mu \mathrm{g})$ did not produce a significant change in paw diameter in either the mutant or wild-type mice ( $p>0.05 ; t$ test; $n=5-7$ per group). In contrast, the licking behavior index of pain produced by intraplantar injection of either serotonin or the two selective $5-\mathrm{HT}_{3} \mathrm{R}$ agonists was significantly reduced in the mutant mice (** $p<0.01 ; t$ test; $n=5-7$ per group). The fact that the magnitude of the pain behavior produced by serotonin was greater than that produced by selective $5-\mathrm{HT}_{3} \mathrm{R}$ agonists indicates that multiple 5-HT receptors contribute to its pronociceptive action.

transcript costained with antisera directed against the vanilloid/ capsaicin receptor VR1, indicating that a minority of $5-\mathrm{HT}_{3}$ responsive neurons are likely to be capsaicin-sensitive nociceptors (Fig. 6e,f).

Interestingly, only $4 \%$ (31 of 739) of the total population of 5- $\mathrm{HT}_{3} \mathrm{R}$-A-positive neurons was also immunoreactive for SP (Fig. $6 g, h)$ and an equivalently small proportion $(4 \% ; 25$ of 656$)$ bound the lectin $\mathrm{IB}_{4}$ (data not shown). Because peripheral release of SP from nociceptors is critical to the swelling associated with neurogenic inflammation (Cao et al., 1998), the minimal overlap between $5-\mathrm{HT}_{3} \mathrm{R}$ and $\mathrm{SP}$ is consistent with the dissociation of $5-\mathrm{HT}_{3} \mathrm{R}$ contribution to pain and inflammation observed in the behavioral studies (Fig. 5). Based on these results, we conclude that the $5-\mathrm{HT}_{3} \mathrm{R}-\mathrm{A}$ is expressed by a subset of neurons with thinly myelinated fibers and by a population of $\mathrm{C}$-fiber neurons, only some of which express traditional markers of nociceptors, notably VR1 and SP.

\section{$5-\mathrm{HT}_{3} \mathrm{R}$ agonists activate both $\mathrm{A} \delta$ - and C-fiber nociceptors}

Because the majority of 5- $\mathrm{HT}_{3} \mathrm{R}$-A-positive neurons do not immunostain for VR1, it is possible that the receptor is predominantly expressed by non-nociceptive primary afferents. To test the hypothesis that $5-\mathrm{HT}_{3} \mathrm{Rs}$ are in fact expressed on capsaicininsensitive $\mathrm{A} \delta$ - and $\mathrm{C}$-fiber nociceptors, we next examined the responses of physiologically characterized primary afferent nociceptors to the application of the 5- $\mathrm{HT}_{3} \mathrm{R}$ agonist $\mathrm{mCPBG}$ in an in vitro skin-saphenous nerve preparation. In this system, cutaneous nociceptors can be examined in situ so as to measure the firing rate of single functionally identified primary afferent neurons during chemical or natural stimulation of their receptive fields. Nociceptors were defined by their response to noxious mechanical stimuli. In wild-type mice, $16 \%$ (5 of 31 ) of $\mathrm{A} \delta$-nociceptors responded to bath-applied mCPBG $(10 \mu \mathrm{M})$ (Fig. $7 a)$. The average number of spikes recorded during the first minute of agonist application was $35 \pm 12.6$ (mean \pm SEM). In contrast, none of the mCPBGresponsive fibers responded to bath application of capsaicin.

Among primary afferent neurons with $\mathrm{C}$-fiber conduction velocities, $29 \%$ (9 of 31 ) responded to $\mathrm{mCPBG}$ application, with an average of $13 \pm 4.2$ spikes in the first minute. The higher $\mathrm{mCPBG}$ evoked activity in A $\delta$-fibers compared with $\mathrm{C}$-fibers is consistent with our observation that the intensity of hybridization signal is greater in neurons with larger cell body diameters. Furthermore, of the nine $\mathrm{mCPBG}$-responsive $\mathrm{C}$-fibers, five were also activated by capsaicin $(10 \mu \mathrm{M})$, an observation that agrees with the anatomical finding that approximately one-half of the $5-\mathrm{HT}_{3} \mathrm{R} \mathrm{C}$-fibers, as defined by the absence of N-52 staining, are immunoreactive for VR1. Importantly, mCPBG never evoked responses in nociceptors from $5-\mathrm{HT}_{3} \mathrm{R}$ mutant mice ( 0 of 15 fibers), confirming the absence of functional receptors in the mutant animals. In other respects, the mice lacking $5-\mathrm{HT}_{3} \mathrm{Rs}$ were identical to littermate controls. This was true for conduction velocities of $\mathrm{A} \delta$-fibers (wild type, $4.9 \pm 0.5$ $\mathrm{m} / \mathrm{sec}$; mutant, $4.9 \pm 1.2 \mathrm{~m} / \mathrm{sec}$ ) and C-fibers (wild type, $0.68 \pm$ $0.03 \mathrm{~m} / \mathrm{sec}$; mutant, $0.67 \pm 0.04 \mathrm{~m} / \mathrm{sec}$ ) and for von Frey mechanical thresholds of $\mathrm{A} \delta$-fibers (median, $9.0 \mathrm{mN}$ for both groups) and $\mathrm{C}$-fibers (median, $5.6 \mathrm{mN}$ for both groups).

Finally, we assessed responsiveness to $\mathrm{mCPBG}$ of cultured DRG neurons isolated from wild-type and mutant mice. The presence of an inflection on the falling phase of the somal action potential was used to distinguish nociceptors from nonnociceptors (Stucky and Lewin, 1999). Again, mCPBG was completely inactive on nociceptors from $5-\mathrm{HT}_{3} \mathrm{R}$ mutant mice $(0 \mathrm{OF}$ 15). Of 70 wild-type neurons, 24 responded to bath application of 3.0 $\mu \mathrm{M} \mathrm{mCPBG}$, and, consistent with the anatomical studies, none of the mCPBG-responsive neurons bound the lectin $\mathrm{IB}_{4}$. The electrophysiological results confirm that the in situ hybridization analysis did not miss a population of small-diameter afferents that bind $\mathrm{IB}_{4}$. In a separate set of DRG cultures, in which 30 of 67 neurons responded to $\mathrm{mCPBG}$, we found that 14 of the 30 mCPBG-responsive nociceptors were N-52 positive (Fig. 7b). Together, the electrophysiological data demonstrate that functional $5-\mathrm{HT}_{3} \mathrm{Rs}$ are found on unique subpopulations of myelinated and unmyelinated nociceptors.

\section{Spinal $5-\mathrm{HT}_{3} \mathrm{Rs}$ facilitate the transmission of nociceptive messages}

Several previous studies reported that spinal delivery of serotonin produces a caudally directed scratching-biting behavior in mice (Fasmer and Post, 1983). This is consistent with a reported pronociceptive effect of $5-\mathrm{HT}_{3} \mathrm{R}$ agonists (Ali et al., 1996) and 

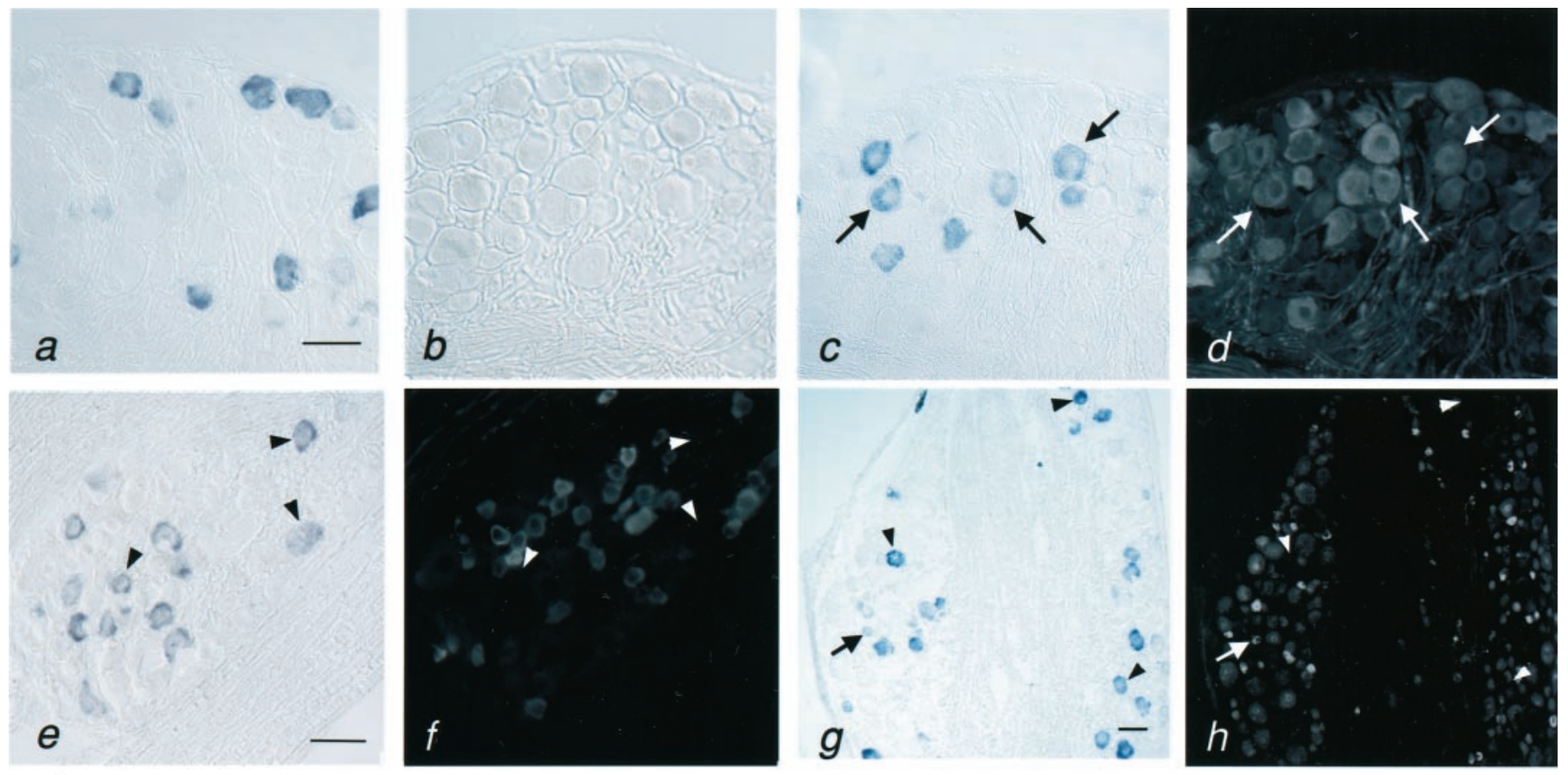

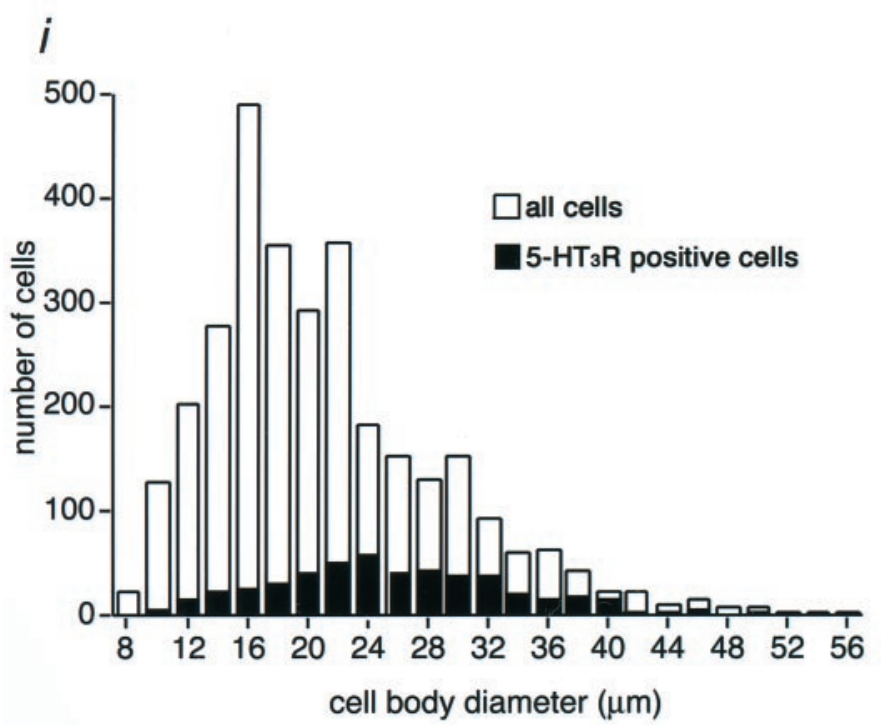

with our observation that intrathecal administration of $5-\mathrm{HT}_{3} \mathrm{R}$ antagonists reduced second-phase behavior in the formalin test (Fig. 4b). In contrast, some studies found an antinociceptive effect of intrathecal 5- $\mathrm{HT}_{3} \mathrm{R}$ agonists and argued that this was mediated via activation of 5- $\mathrm{HT}_{3} \mathrm{Rs}$ on GABAergic inhibitory interneurons (Glaum et al., 1990; Alhaider et al., 1991). Because the knock-out mice provide a more specific assessment of the contribution of a particular receptor subtype, we examined the effect of intrathecal injections of serotonin or selective $5-\mathrm{HT}_{3} \mathrm{R}$ agonists in wild-type and mutant mice.

Consistent with the pronociceptive effects noted above, in the wild-type mice, we observed a dose-dependent scratching behavior of the lower back after intrathecal administration of $0.2-20 \mu \mathrm{g}$ of serotonin (Fig. 8a). In mutant mice, the scratching response to intrathecal serotonin was significantly reduced. Surprisingly, the selective $5-\mathrm{HT}_{3} \mathrm{R}$ agonist $m$-chlorophenyl-biguanide did not pro-
Figure 6. Subsets of DRG neurons contain 5- $\mathrm{HT}_{3} \mathrm{R}-\mathrm{A}$ mRNA. In situ hybridization in wild-type mice $(\dot{a})$ and the absence of signal in 5-HT ${ }_{3} \mathrm{R}-\mathrm{A}$ null mutant mice $(b)$ confirms the probe specificity. The vast majority of 5- $\mathrm{HT}_{3} \mathrm{R}$ mRNA-positive neurons $(c)$ immunostain for N52 $(d)$, a neurofilament marker of myelinated axons. Note that the doublelabeled neurons (arrows) are of medium $(\sim 30 \mu \mathrm{m})$ diameter. There is minimal overlap between the $5-\mathrm{HT}_{3} \mathrm{R}-\mathrm{A}$ neuronal population $(e)$ and the subset of neurons that express VR1 $(f)$. Arrowheads highlight examples of 5-HT $\mathrm{T}_{3} \mathrm{R}$-A-positive neurons that are not immunoreactive for VR1. Virtually none of the 5-HT ${ }_{3} \mathrm{R}-\mathrm{A}$-positive neurons $(\mathrm{g})$ immunostain for SP (h). Arrow indicates a rare double-labeled cell, and arrowheads highlight 5-HT $\mathrm{H}_{3} \mathrm{R}$-A-positive neurons that are not immunoreactive for SP. Size distribution of 5- $\mathrm{HT}_{3} \mathrm{R}-\mathrm{A}$-positive neurons in the adult mouse DRG $(i)$. Only cells with visible nuclei were measured. Scale bars: $50 \mu \mathrm{m}$ ( $a$ applies to $a-d ; e$ applies to $e$ and $f ; g$ applies to $g$ and $h$ ).

duce scratching behavior in wild-type mice $(0.02-20 \mu \mathrm{g})$ (data not shown). This suggests that the $5-\mathrm{HT}_{3} \mathrm{R}$ is necessary, but not sufficient, for serotonin-mediated scratching (pain) behavior; other 5-HT receptors must act in concert to produce the behavior. Finally, although we found that the same dose of serotonin had an antinociceptive effect in the hot-plate test, there was no difference between the wild-type and mutant mice. At the highest dose $(20 \mu \mathrm{g})$, intrathecal serotonin increased the hot-plate latency by $54 \pm 5$ and $47 \pm 7 \%$ in the wild-type and mutant mice, respectively (Fig. $8 b$ ). We conclude that the $5-\mathrm{HT}_{3} \mathrm{R}$ is not involved in the antinociceptive effect of serotonin.

\section{DISCUSSION}

Based on the results of the present study, we can draw several important conclusions concerning the mechanisms through which activity at the $5-\mathrm{HT}_{3} \mathrm{R}$ contributes to nociceptive processing and 


\section{a Mechanical indentation $(\mu \mathrm{m})$}

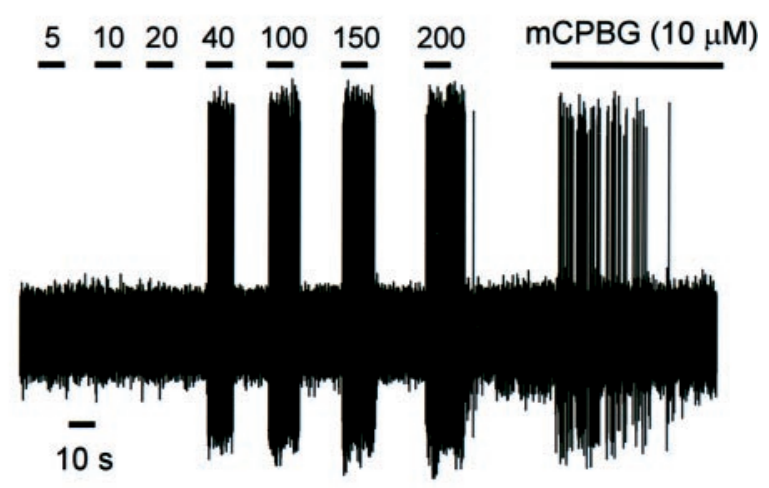

b
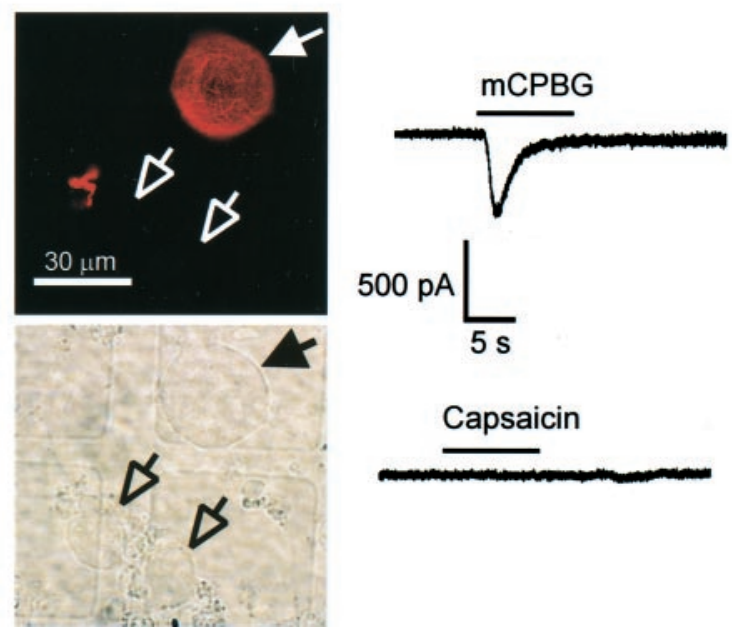

\section{Capsaicin}

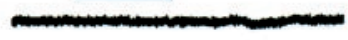

Figure 7. Reponses of primary afferent neurons to the $5-\mathrm{HT}_{3} \mathrm{R}$ agonist mCPBG. $a$, Recording from a single A $\delta$-fiber nociceptor (conduction velocity, $2.63 \mathrm{~m} / \mathrm{sec}$ ) in a skin-nerve preparation from a wild-type mouse. Fiber responded with action potentials only to high-intensity mechanical stimuli ( $\geq 40 \mathrm{~mm}$ indentation) and encoded the mechanical stimuli well, with slowly adapting responses to $10 \mathrm{sec}$ sustained indentation. The fiber responded vigorously during the first minute of mCPBG $(10 \mu \mathrm{M})$ application but did not respond to subsequent application of capsaicin $(10 \mu \mathrm{M})$ (data not shown). $b$, Left, Fluorescent and phase images of a wild-type DRG neuron that was immunoreactive for neurofilament antibody N-52 (filled arrowhead). Open arrowheads indicate two smaller neurons that were negative for N-52. Right, Patch-clamp recordings from the N-52immunoreactive neuron show that the neuron responded to mCPBG (3 $\mu \mathrm{M})$ but not to capsaicin $(3 \mu \mathrm{M})$.

pain. First, the $5-\mathrm{HT}_{3} \mathrm{R}$ is not required for acute nociception in response to physiological stimuli. Second, the $5-\mathrm{HT}_{3} \mathrm{R}$ contributes to persistent nociceptive processing without inducing a concomitant edema in the setting of injury. Third, the peripheral $5-\mathrm{HT}_{3} \mathrm{R}$ contribution is via an action on both myelinated and unmyelinated nociceptors. On the other hand, although these afferents are activated in the setting of tissue injury, in the models that we used we found no behavioral evidence to implicate the $5-\mathrm{HT}_{3} \mathrm{R}$ in their sensitization. This conclusion is based on the fact that profound allodynia developed in both wild-type and mutant mice after paw injections of CFA or after partial nerve injury. Thus, we hypothesize that activation, but not sensitization, of primary afferents results from a serotonin action at the $5-\mathrm{HT}_{3} \mathrm{R}$. It is, of course, possible that the contribution of $5-\mathrm{HT}_{3} \mathrm{Rs}$ is dependent on the particular model used to test sensitization. For example, it may come into play in which there are allergic reactions (e.g., bee

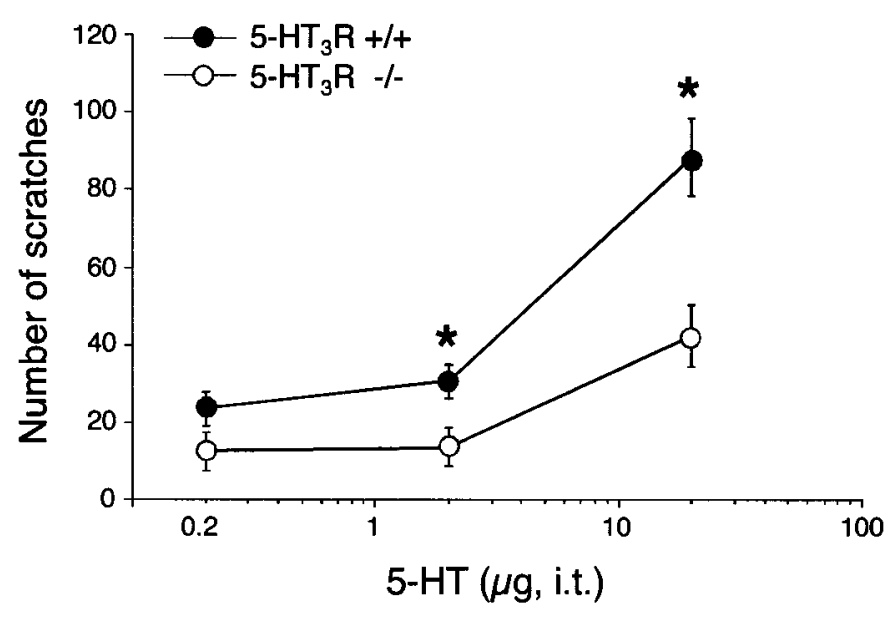

Figure 8. Spinal 5- $\mathrm{HT}_{3} \mathrm{Rs}$ facilitate the transmission of nociceptive messages. Intrathecal injection of serotonin produced a dose-dependent caudally directed scratching behavior (0-3 min) and an increase in the response latency on the $52.5^{\circ} \mathrm{C}$ hot-plate test. Mutant mice showed significantly less scratching behavior ( ${ }^{*} p<0.01 ; t$ test; $n=5$ per group) but showed a similar antinociceptive effect compared with wild-type mice after spinal delivery of serotonin.

sting-induced inflammation). Finally, we provide evidence that central serotonergic circuits modulate nociceptive processing via a facilitatory action at spinal $5-\mathrm{HT}_{3} \mathrm{Rs}$.

Release of serotonin in the setting of injury thus has multiple consequences. Serotonin directly activates nociceptive afferents to increase the barrage of impulses transmitted to the spinal cord, resulting in an increase in behaviors indicative of pain. It also contributes to peripheral neurogenic inflammation, via activation of small-diameter peripheral afferents and release of proinflammatory peptides, such as SP from peripheral terminals. The latter induces extravasation of proteins from postcapillary venules, which in turn contributes to peripheral edema (Lembeck et al., 1982). The contributions of serotonin to nociception-pain and swelling, however, are readily dissociable according to the receptors that are activated. We found that peripheral injection of serotonin produced both pain behavior and swelling of the hindpaw in wild-type mice, but only the former was reduced in the $5-\mathrm{HT}_{3} \mathrm{R}$ null mutant mice. Consistent with these results, we found that $5-\mathrm{HT}_{3} \mathrm{R}$ agonists also induced paw licking, but the paw did not concomitantly swell. Finally, we found that, despite a reduction of pain behavior in the null mutant mice when tissue injury was induced with formalin, swelling was not affected. This result agrees with a report showing that $5-\mathrm{HT}_{3} \mathrm{R}$ antagonists reduced the pain behaviors but not the inflammation evoked by carrageenan (Eschalier et al., 1989). It is likely that serotonin-induced edema involves activation of 5- $\mathrm{HT}_{2 \mathrm{a}}$ receptors (Pierce et al., 1995; Germonpré et al., 1997). The fact that the 5-HT ${ }_{3} \mathrm{R}$ appears not to contribute to the edema component of the neurogenic inflammatory response is, of course, consistent with our finding that 5- $\mathrm{HT}_{3} \mathrm{R}-\mathrm{A}$ message and substance $\mathrm{P}$ immunoreactivity did not colocalize in DRG neurons.

Previous studies reported that dorsal rhizotomy or neonatal capsaicin treatment significantly reduces the binding of ${ }^{3} \mathrm{H}$ zacopride (a $5-\mathrm{HT}_{3} \mathrm{R}$ radioligand) in the superficial dorsal horn (Hamon et al., 1989; Kidd et al., 1993). Because the terminals of unmyelinated primary afferents predominantly synapse in the superficial dorsal horn, it has been assumed that the $5-\mathrm{HT}_{3} \mathrm{R}$ is expressed primarily on capsaicin-sensitive $\mathrm{C}$-fiber nociceptors. In 
fact, our anatomical and electrophysiological results indicate that the majority of nociceptors that express the $5-\mathrm{HT}_{3} \mathrm{R}$ are capsaicin insensitive. Rather, the $5-\mathrm{HT}_{3} \mathrm{R}$ is predominantly expressed by myelinated (i.e., N-52-positive) A $\delta$ afferents and by small but unique population of $\mathrm{C}$-fibers, which overlaps to some extent with both the traditional peptidergic (substance P-containing) and nonpeptidergic subpopulations (Snider and McMahon, 1998). Importantly, our results are in accord with a previous study of blood pressure regulation, which concluded that $5-\mathrm{HT}_{3} \mathrm{R}$ agonists and capsaicin stimulate different populations of vagal afferent fibers (Skofitsch et al., 1983).

Finally, we provide strong evidence that nociceptive processing is enhanced via an action at a spinal cord $5-\mathrm{HT}_{3} \mathrm{R}$. Specifically, we found that the second-phase behavior in the formalin test was significantly reduced after intrathecal administration of the 5- $\mathrm{HT}_{3} \mathrm{R}$ antagonist ondansetron, as has been reported in the rat (Oyama et al., 1996). Because the antagonist did not alter nociceptive thresholds when it was administered alone, i.e., in the absence of ongoing injury, there does not appear to be a tonic action of serotonin at the $5-\mathrm{HT}_{3} \mathrm{R}$. Rather, spinal cord levels of serotonin must be increased under conditions of injury (and presumably of pain). Indeed, noxious stimulus-evoked release of serotonin into the spinal CSF has been described previously (Tyce and Yaksh, 1981). It is generally assumed that descending serotonergic pathways mediate an inhibition of nociceptive processing at the level of the spinal cord (Basbaum and Fields, 1984), in part via $5-\mathrm{HT}_{3} \mathrm{R}$-mediated activation of GABAergic inhibitory interneurons (Alhaider et al., 1991). Our results suggest that spinal $5-\mathrm{HT}_{3} \mathrm{Rs}$ predominantly mediate a positive feedback that enhances nociceptive processing at the spinal cord level. Interestingly, Zhuo and Gebhart (1991) used electrical stimulation or glutamate microinjection into the rostroventral medulla to activate descending serotonergic axons and found a facilitation of nociceptive processing that could be blocked by intrathecal injection of $5-\mathrm{HT}_{1} \mathrm{R}$ antagonists. Our results indicate that parallel $5-\mathrm{HT}_{3} \mathrm{R}$-mediated facilitation also occurs, and they establish the conditions under which this facilitation comes into play, namely in the setting of tissue injury. Given that the $5-\mathrm{HT}_{3} \mathrm{R}$ is found on many spinal cord neurons, we cannot determine whether the positive feedback is exerted via an action on the central terminals of primary afferents that express the receptor or on postsynaptic dorsal horn neurons.

In summary, using a combined genetic, pharmacological, electrophysiological, and anatomical approach, we provided new insights into the contribution of the $5-\mathrm{HT}_{3} \mathrm{R}$ to nociceptive processing and inflammation. Our results are consistent with the fact that 5- $\mathrm{HT}_{3} \mathrm{R}$ antagonists, which held initial promise as analgesic drugs, cannot by themselves provide satisfactory pain relief in patients (Greenshaw and Silverstone, 1997; Hamon et al., 1999). Because the great majority of $\mathrm{C}$ nociceptors do not express the $5-\mathrm{HT}_{3} \mathrm{R}$, it follows that the pain that arises from activation of these afferents will be refractory to $5-\mathrm{HT}_{3} \mathrm{R}$ antagonists. For this reason, we suggest that a combination of $5-\mathrm{HT}_{3} \mathrm{R}$ antagonists with drugs that interfere with the transmission of messages conveyed by unmyelinated afferents may provide a more effective approach to the relief of pain in the setting of injury.

\section{REFERENCES}

Alhaider AA, Lei SZ, Wilcox GL (1991) Spinal 5-HT 3 receptormediated antinociception: possible release of GABA. J Neurosci 11:1881-1888.

Ali Z, Wu G, Kozlov A, Barasi S (1996) The role of $5 \mathrm{HT}_{3}$ in nociceptive processing in the rat spinal cord: results from behavioural and electrophysiological studies. Neurosci Lett 208:203-207.

Basbaum AI, Fields HL (1984) Endogenous pain control systems: brainstem spinal pathways and endorphin circuitry. Annu Rev Neurosci 7:309-338.

Bockaert J, Sebben M, Dumuis A (1990) Pharmacological characterization of 5-hydroxytryptamine $4\left(5-\mathrm{HT}_{4}\right)$ receptors positively coupled to adenylate cyclase in adult guinea pig hippocampal membranes: effect of substituted benzamide derivatives. Mol Pharmacol 37:408-411.

Cao YQ, Mantyh PW, Carlson EJ, Gillespie AM, Epstein CJ, Basbaum AI (1998) Primary afferent tachykinins are required to experience moderate to intense pain. Nature 392:390-394.

Chaplan SR, Bach FW, Pogrel JW, Chung JM, Yaksh TL (1994) Quantitative assessment of tactile allodynia in the rat paw. J Neurosci Methods 53:55-63.

Chen CC, Akopian AN, Sivilotti L, Colquhoun D, Burnstock G, Wood JN (1995) A P2X purinoceptor expressed by a subset of sensory neurons. Nature 377:428-431.

Davies PA, Pistis M, Hanna MC, Peters JA, Lambert JJ, Hales TG, Kirkness EF (1999) The 5- $\mathrm{HT}_{3} \mathrm{~B}$ subunit is a major determinant of serotonin-receptor function. Nature 397:359-363.

Dickenson AH, Sullivan AF (1987) Subcutaneous formalin-induced activity of dorsal horn neurones in the rat: differential response to an intrathecal opiate administered pre or post formalin. Pain 30:349-360.

Dray A (1995) Inflammatory mediators of pain. $\mathrm{Br} \mathrm{J}$ Anaesth 75:125-131.

Dubner R, Basbaum AI (1994) Spinal dorsal horn plasticity following tissue or nerve injury. In: Textbook of pain (Wall PD, Melzack R, eds), pp 225-241. New York: Churchill Livingston.

Eschalier A, Kayser V, Guilbaud G (1989) Influence of a specific 5-HT antagonist on carrageenan-induced hyperalgesia in rats. Pain 36:249-255.

Fasmer OB, Post C (1983) Behavioural responses induced by intrathecal injection of 5-hydroxytryptamine in mice are inhibited by a substance $\mathrm{P}$ antagonist, D-Pro2, D-Trp7,9-substance P. Neuropharmacology 22:1397-1400.

Gehlert DR, Gackenheimer SL, Wong DT, Robertson DW (1991) Localization of $5-\mathrm{HT}_{3}$ receptors in the rat brain using [ $\left.{ }^{3} \mathrm{H}\right] \mathrm{LY} 278584$. Brain Res 553:149-154.

Germonpré PR, Joos GF, Mekeirele K, Pauwels RA (1997) Role of the 5 -HT receptor in neurogenic inflammation in Fisher 344 rat airways. Eur J Pharmacol 324:249-255.

Glaum SR, Proudfit HK, Anderson EG (1990) 5- $\mathrm{HT}_{3}$ receptors modulate spinal nociceptive reflexes. Brain Res 510:12-16.

Greenshaw AJ, Silverstone PH (1997) The non-antiemetic uses of serotonin $5-\mathrm{HT}_{3}$ receptor antagonists. Clinical pharmacology and therapeutic applications. Drugs 53:20-39.

Hamon M, Bourgoin S (1999) Serotonin and its receptors in pain control. In: Novel aspects of pain management: opioids and beyond (Sawynok J, Cowan A, eds), pp 203-228. New York: Wiley.

Hamon M, Gallissot MC, Menard F, Gozlan H, Bourgoin S, Vergé D (1989) $5-\mathrm{HT}_{3}$ receptor binding sites are on capsaicin-sensitive fibres in the rat spinal cord. Eur J Pharmacol 164:315-322.

Hargreaves K, Dubner R, Brown F, Flores C, Joris J (1988) A new and sensitive method for measuring thermal nociception in cutaneous hyperalgesia. Pain 32:77-88.

Kia HK, Miquel MC, McKernan RM, Laporte AM, Lombard MC, Bourgoin S, Hamon M, Vergé D (1995) Localization of 5-HT 3 receptors in the rat spinal cord: immunohistochemistry and in situ hybridization. NeuroReport 6:257-261.

Kidd EJ, Laporte AM, Langlois X, Fattaccini CM, Doyen C, Lombard MC, Gozlan H, Hamon M (1993) 5- $\mathrm{HT}_{3}$ receptors in the rat central nervous system are mainly located on nerve fibres and terminals. Brain Res 612:289-298.

Koltzenburg M, Stucky CL, Lewin GR (1997) Receptive properties of mouse sensory neurons innervating hairy skin. J Neurophysiol 78:1841-1850.

Lawson SN, Waddell PJ (1991) Soma neurofilament immunoreactivity is related to cell size and fibre conduction velocity in rat primary sensory neurons. J Physiol (Lond) 435:41-63.

Lembeck F, Donnerer J, Barthó L (1982) Inhibition of neurogenic vasodilation and plasma extravasation by substance $\mathrm{P}$ antagonists, somatostatin and [D-Met2, Pro5]enkephalinamide. Eur J Pharmacol 85:171-176.

Lewis C, Neidhart S, Holy C, North RA, Buell G, Surprenant A (1995) Coexpression of $\mathrm{P} 2 \mathrm{X}_{2}$ and $\mathrm{P} 2 \mathrm{X}_{3}$ receptor subunits can account for ATP-gated currents in sensory neurons. Nature 377:432-435.

Malmberg AB, Basbaum AI (1998) Partial sciatic nerve injury in the mouse as a model of neuropathic pain: behavioral and neuroanatomical correlates. Pain 76:215-222.

Maricq AV, Peterson AS, Brake AJ, Myers RM, Julius D (1991) Primary structure and functional expression of the $5 \mathrm{HT}_{3}$ receptor, a serotoningated ion channel. Science 254:432-437.

Martin GR, Eglen RM, Hamblin MW, Hoyer D, Yocca F (1998) The 
structure and signalling properties of 5-HT receptors: an endless diversity? Trends Pharmacol Sci 19:2-4.

Martin WJ, Malmberg AB, Basbaum AI (2001) PKC $\gamma$ contributes to a subset of the NMDA-dependent spinal circuits that underlie injuryinduced persistent pain J Neurosci 21:5321-5327.

Oyama T, Ueda M, Kuraishi Y, Akaike A, Satoh M (1996) Dual effect of serotonin on formalin-induced nociception in the rat spinal cord. Neurosci Res 25:129-135.

Pierce PA, Xie GX, Peroutka SJ, Green PG, Levine JD (1995) 5-Hydroxytryptamine-induced synovial plasma extravasation is mediated via 5-hydroxytryptamine $2 \mathrm{~A}$ receptors on sympathetic efferent terminals. J Pharmacol Exp Ther 275:502-508.

Rang HP, Bevan S, Dray A (1994) Nociceptive peripheral neurons: cellular properties. In: The textbook of pain (Wall PD, Melzack R, eds), pp 57-78. London: Churchill Livingstone.

Richardson BP, Engel G, Donatsch P, Stadler PA (1985) Identification of serotonin M-receptor subtypes and their specific blockade by a new class of drugs. Nature 316:126-131.

Skofitsch G, Saria A, Lembeck F (1983) Phenyldiguanide and capsaicin stimulate functionally different populations of afferent $\mathrm{C}$-fibers. Neurosci Lett 42:89-94.

Snider WD, McMahon SB (1998) Tackling pain at the source: new ideas about nociceptors. Neuron 20:629-632.

Stucky CL, Lewin GR (1999) Isolectin B(4)-positive and -negative nociceptors are functionally distinct. J Neurosci 19:6497-6505.

Sufka KJ, Schomburg FM, Giordano J (1992) Receptor mediation of
5-HT-induced inflammation and nociception in rats. Pharmacol Biochem Behav 41:53-56.

Tecott LH, Maricq AV, Julius D (1993) Nervous system distribution of the serotonin 5- $\mathrm{HT}_{3}$ receptor mRNA. Proc Natl Acad Sci USA 90:1430-1434.

Tjølsen A, Berge OG, Hunskaar S, Rosland JH, Hole K (1992) The formalin test: an evaluation of the method. Pain 51:5-17.

Tyce GM, Yaksh TL (1981) Monoamine release from cat spinal cord by somatic stimuli: an intrinsic modulatory system. J Physiol (Lond) 314:513-529.

Wei F, Wang G, Kerchner GA, Kim SJ, Zu H, Chen Z, Zhuo M (2001) Genetic enhancement of inflammatory pain by forebrain NR2B overexpression. Nat Neurosci 4:164-169.

Werner P, Kawashima E, Reid J, Hussy N, Lundström K, Buell G, Humbert Y, Jones KA (1994) Organization of the mouse $5-\mathrm{HT}_{3}$ receptor gene and functional expression of two splice variants. Brain Res Mol Brain Res 26:233-241.

Wong EH, Bonhaus DW, Lee JA, Wu I, Loury DN, Eglen RM (1993) Different densities of $5-\mathrm{HT}_{3}$ receptors are labeled by $\left[{ }^{3} \mathrm{H}\right]$ quipazine, $\left[{ }^{3} \mathrm{H}\right] \mathrm{GR} \quad 65630$ and $\left[{ }^{3} \mathrm{H}\right]$ granisetron. Neuropharmacology $32: 869-875$

Zhuo M, Gebhart GF (1991) Spinal serotonin receptors mediate descending facilitation of a nociceptive reflex from the nuclei reticularis gigantocellularis and gigantocellularis pars alpha in the rat. Brain Res 550:35-48. 